\title{
Ecological Potentials of Beekeeping in Mayo-Belwa Local Government Area of Adamawa State, Nigeria
}

\author{
Mohammed Abdullahi ${ }^{1 *}$, Amit Larkin ${ }^{1}$, Hemant Kumar ${ }^{1}$ and B.T. Kwaga ${ }^{2}$ \\ ${ }^{1}$ College of Forestry, Sam Higgingbottom, University of Agriculture, \\ Tech. \& Sci., Prayagraj, India \\ ${ }^{2}$ Department of Forestry \& Wildlife Management, Modibbo Adama University of Technology, \\ Yola, Nigeria \\ *Corresponding author
}

\begin{abstract}
Keywords
Beekeeping,

Ecological

potentials,

Inventory of plant

resources, Mayo-

Belwa

\section{Article Info}

Accepted:

12 April 2019

Available Online:

10 May 2019 resources utilized by honeybees, determine density of both tree and shrub species as well as estimate the cover of herbaceous plant species in the study area. Total count methods were done for trees and shrubs, while herbaceous plant cover was estimated in quadrat by the ocular estimate method. Secondary data on precipitation, Temperature and Relative humidity were collected from the nearest meteorological station to the study site and also the yield of honey were obtained from the beekeepers in the study area. Descriptive statistics, analysis of variance and multiple regressions were employed for analysis. Results obtained showed that 14 species of trees belong to 10 families, 11 species of shrubs under 7 families and 6 species of herbaceous plants from 4 families were identified as plants utilized by honeybees in the study area. Among the trees inventoried, $85.7 \%$ and $92.9 \%$ were utilized by bees in districts 1 and 2 respectively, while $90.9 \%$ and $81.8 \%$ of shrubs were also utilized by bees in the study area. $70.4 \%$ and $58.8 \%$ of herbaceous plant cover were utilized by honeybees in the study area while Precipitation $\left(-0.207^{\mathrm{ns}}\right)$ and temperature $\left(-3.476^{\mathrm{ns}}\right)$ had no significant on the yield of honey, the effect of tree density on yield of honey was significant $(0.524 *)$ and that of Relative humidity was highly significant $(1.492 * *)(\mathrm{P}<0.05)$. The results showed that the study area has ecological potentials for beekeeping. To improve the beekeeping in the study area, training programs either through workshops or extension services are recommended.
\end{abstract}

\section{A B S T R A C T}

This study was undertaken to determine the ecological potentials of beekeeping in MayoBelwa local Government Area of Adamawa state. Following the randomly selection of two districts based on the existing forest reserves in the local government area, the inventory of plant resources at both woody and herbaceous layer were made to prepare the list of plant

\section{Introduction}

Beekeeping is one of the most ancient crafts known to man, evolving naturally from the skills of those who gathered honey from the wild. The Roman era brought wide spread use of clay hives and this continued to be used up to the time of industrial revolution in Britain at the time cheap imported sugar and refined mineral oils threatened the production of 
honey and wax (Campbell and Lesley, 1985). In Nigeria, during the middle age (10001500AD), Arab travelers in West Africa which includes Northern Nigeria recorded the use of honey as food and referred to the existence of bee hives and honey. Beekeeping activities can contribute and generates more income to the millions of famers in Ethiopia (Reda et al., 2018).

Honeybees are four-winged insects with a sting. There are over 12,000 species around the world but only about 600 of these species are social in habit. Among the social bees are the honey bees. They belong to the animal kingdom, phylum Arthropoda, class-insecta, order-Humenoptera, family-Apidae, GenusApis and species Mellifera. There social individuals consists of the Queen, drones, and workers, each caste having a specific role to play (Wanda, 2003). The Queen is the only female honey bee that is completely developed sexually. The drones are the male honey bees without stings whose role is to mate with the Queen. The workers are females that perform the work of building and repairing of hives depending on need. Queen could live for about 2-5 years, drone 28-35 days and workers 2-6 months depending on availability of forage and hive resources (Brain, 1983; Reinhard, 1997; Wanda; 2003).

Beekeeping is one of the branches of agriculture and a form of animal husbandry that includes the collection and care of bee swarms, pollination of field crops by the bees and breeding of bees for various products. It is a special agricultural enterprise that served as foreign exchange earner for some countries within and outside Africa (Beetsma et al., 1997). Unfortunately beekeeping as a commercial venture is still largely unexplored in Nigeria. This field is still at the crude stage with the exception of few farms and individuals trying to keep pace with modern beekeeping method. It is also worthy of note that little research, training and academic work on beekeeping has been done in Nigeria. For the local government under study, absolutely nothing has been done on beekeeping. This can be broadly attributed to the lack of public awareness about bees and modern beekeeping, even though the hive products like honey are generally accepted and of importance. The ancient beekeeping started with an understanding of life cycle of bees and the structure of the hives. Basket, wet bags, clay pot were used in capturing swarms but this practice changed between 1500 and 1851 as reported by Carol (2003).

Beekeeping in Mayo-Belwa local government is basically categorized in to two. Honey hunting and traditional beekeeping. Honey hunting is the invasion of wild bee colonies at night or any other convenient period to harvest stored honey. This method is very destructive and could lead to death of high population of bees. The traditional method involves the keeping of bee colonies using traditional methods and materials like woven grasses, clay pots, tree barks and log of wood which is an improvement method on honey hunting. However, the modern beekeeping involves the making of top-bar hives from wood and is easier to handle while dealing with bee colonies. This method is currently lacking or non-existent in Mayo-Belwa local government with the exception of few farms and individuals despite the abundant plant/forest resources (Reinhard, 1995). The abundant of several gazette and proposed forest reserves with varying species may also contribute to the success of beekeeping in the area (Akosim et al., 1999).

The bees visit many flowers of native trees, shrubs and herbaceous plants. Among those trees visited are sheabutter tree (Vitellaria paradoxum), locust bean tree (Parkia biglobosa), mahogany (Khayasenegalensis), Guava (Psidium guava). Flowers of Tridax 
procumbens and Aspelia africana are also visited by bees just to mention a few (Marieke, 1991). The practice of beekeeping contributes significantly to the economy of beekeepers and hunters in one way or the other as well as serving as source of food, educational purposes as well as agriculture (Curtis and Stacey, 1982; Ikediobi and Obi, 1985; Onyekuru, 1985; Ijomah and Akosim, 2000).

Scientific information regarding the ecological potentials of beekeeping in the study area is necessary for planning and determination of viability of beekeeping industry in the area. However, survey that can yield data on the ecological potentials of beekeeping in the area under study is yet to be carried out, hence the necessity for this study which provided baseline information on the checklist of plants visited by honeybees in the study area. It was equally revealed the plant density and the proportions used by honeybees in the study area as well as examined the effects of ecological factors on the yield of honey in the study area.

\section{Materials and Methods}

\section{Study area}

The study area is mayo-Belwa local government area and it is located in the southern senatorial district of Adamawa state, Nigeria with its headquarters situated sixtyfive kilometers away from Yola. The local government lies on latitudes $9^{0} 3^{\prime} 0^{\prime \prime} \mathrm{N}$ and longitudes $12^{0} 3^{\prime} 0^{\prime} \mathrm{E}$ (Mayo Belwa Google map, 2019). Means monthly temperatures ranges from $25^{\circ} \mathrm{C}$ to $33^{\circ} \mathrm{C}$ while relative humidity varies from $22 \%$ to $53 \%$ in January and November respectively. Annual rainfall ranges from $900 \mathrm{~mm}$ to $1100 \mathrm{~mm}$ and last for about 6-7 months (Adebayo and Tukur, 1999). The study area is a guinea savannah zone with abundant species of trees among which are the woody species of Vitella riaparadoxa, Balanites aegyptiaca, Ceiba pentandra, Parkia, Prosopis africana, Vitex doniana and many others. Grass species in the study area are Andropogon, Hypourherid, Panicum spp and Hyparrhenia spp (Akosim et al., 1999).

\section{Study design and data collection}

The study design were involved the random selection of two districts (Mayo-belwa and Binyeri) out of the five existing ones. Five (5) plots of one hectare each were randomly selected in each of the district based on the existing forest reserves (making a total of 10 plots of one hectare each). Total count of individual of trees and shrubs as outlined by Sutherland (1999) and adopted by Akosim et.al. (2007) were used. Data on woody and herbaceous plant species visited and utilized by honeybees in the study area were obtained through visual assessment of the plants following the method described byAkosim et al., (2007); Akobundu and Agyakwa (1998). Secondary data on rainfall, temperature and relative humidity for the period of 2 Years (2009-2010) were collected from Upper Benue River Basin Development Authority, Yola (UBRBDA, 2011). Yield of honey in the study area were obtained from the management of Sebore Farms, from twelve (12) hives for the period of two Years (20092010) (Sebore Farms record, 2011).

\section{Data analysis}

Descriptive statistics (use of tables, percentages and means) were used in presenting the list, period of visit and utilization of plant species by honeybees in the study area based on Wahu'a (1999); Swamy (2002) principles. Data collected were subjected to one way analysis of variance (ANOVA), using Completely Randomized Designed (CRD) model for determining the 
plant species density in the study area. The model described by Gomez and Gomez (1984) which is illustrated as follow:

$\mathrm{Y}_{\mathrm{ij}}=\mu+\mathrm{t}_{\mathrm{i}}+\sum_{\mathrm{ij}}$

Where:

$\mathrm{Y}_{\mathrm{ij}}=$ Mean of individual observation, $\mu=$ General mean, $\mathrm{t}_{1}=$ Treatment effect,

$\sum_{\mathrm{ij}}=$ Experimental error.

Also multiple regression models as adopted by Akosim et al., (2007) were used in determining the effects of climatic factors, woody and herbaceous plant species on the yield of honey in the study area. The formula is given as follows:

$\mathrm{Y}=\mathrm{a}+\mathrm{b}_{1} \mathrm{x}_{1}+\mathrm{b}_{2} \mathrm{x}_{2}+\mathrm{b}_{3} \mathrm{x}_{3}+\mathrm{b}_{4} \mathrm{X}_{4}+\mathrm{e}$

Where:

$\mathrm{Y}=$ Yields of honey $(\mathrm{kg}), \mathrm{a}=$ slope, $\mathrm{b}_{1} \mathrm{~b}_{2} \mathrm{~b}_{3}$ and $\mathrm{b}_{4}=$ Regression coefficient, $\mathrm{X}_{1}=$ Rainfall (mm)

$\mathrm{X}_{2}=$ Relative humidity $(\%), \quad \mathrm{X}_{3}=$ Temperature $\left(0^{\mathrm{C}}\right), \mathrm{X}_{4}=$ Tree density $(\mathrm{No} / \mathrm{ha})$, $\mathrm{e}=$ Error term .

\section{Results and Discussion}

The check list of plants utilized by honeybees in the study area (Table 1) shows that 14 tree species belong to 10 families, 11 shrub species under 7 families and 6 herbaceous plants from 4 families were identified. The results of tree species density in district 1(Mayo-Belwa) (Table 2) indicates that Vitellaria paradoxa (4.000/hectare) and Ficus sycomorus (1.000/hectare) were the highest and the least density respectively. It also indicates that (12) or $85.7 \%$ of the identified species are utilized by honeybees in the study area. The results of tree species density in district 2(Binyeri) (Table 3) shows that Vitex doniana (4.500/hectare) and Acacia sieberina (1.500/hectare) were the highest and the lowest density respectively. It also indicates that (13) or $92.9 \%$ of the identified species are utilized by the honeybees in the study area. Results of comparison of tree species density in the study area, District by District is shown in (Table 4) that District 2 (Binyeri) (36.500/hectare) had the highest tree density while District 1(Mayo-Belwa) had the lowest (33.872/hectare). It also indicates that there is significant difference at $(\mathrm{P}<0.05)$ density of the trees among the two Districts in the study area. (Table 5) shows the results of shrubs species density in District 1(MayoBelwa) that Annona senegalensis (5.500/hectare) and Moringa olifera (1.000/hectare) were the highest and the least densities respectively in the study area. It also indicated that (10) or $90.9 \%$ of the identified species are utilized by honeybees in the study area. The results of shrubs species density in District 2(Binyeri) (Table 6) shows that Annona senegalensis (4.800/ hectare) and Acacia ataxacantha (1.000/hectare) recorded the highest and the least density respectively. The result equally shows that (9) or $81.8 \%$ of the identified species are utilized by honeybees in the study area. Results of comparison of shrubs species density in the study area (Table 7) indicates that District 1(Mayo-Belwa) (32.900/hectare) had the highest shrubs density while District 2(Binyeri) had the least $(28.500$ /hectare). It also indicates there is significant difference at $(\mathrm{P}<0.05)$ in density of shrubs among the two districts in the study area. (Table 8) indicates the results of the percentage cover of herbaceous plants utilized by honeybees in District 1(Myo-Belwa) and 2(Binyeri) of the study area, are $70.4 \%$ and $58.5 \%$ respectively. The results also shows that there is significantly difference at $(\mathrm{P}<0.05)$ among the two Districts.(Table 9) shows the results of the effects of climatic factors (Rainfall, Temperature, Relative humidity and plants density) on the yield of honey in the study area. The results indicated that relative 
humidity (coefficient $1.492^{* *}$ ) is the most significant factor followed by tree density $\left(0.524^{*}\right)$ contributing to the yield of honey as against rainfall $\left(-0.207^{\mathrm{ns}}\right)$ and temperature ($3.476^{\mathrm{ns}}$ ) in the study area. The total number of tree species (14) belonging to 10 families and shrub species (11) under 7 families as well as herbaceous species (6) from 4 families respectively makes up $50 \%$ of the plants species recorded by Akosim et al., (2007) for beekeeping in Adamawa state. The above result indicates high availability of forage resources needed by the honeybees for food and shelter in the study area.

Table.1 Check list of plants utilized by honeybees in the study area

\begin{tabular}{|c|c|c|c|c|c|}
\hline $\mathbf{S} / \mathbf{N}$ & \multicolumn{2}{|c|}{ A- Tree Species } & $\begin{array}{c}\text { Common Name/ } \\
\text { Hausa Name }\end{array}$ & $\begin{array}{l}\text { Morning } \\
\text { Period visit } \\
\end{array}$ & $\begin{array}{r}\text { Evening } \\
\text { Period visit } \\
\end{array}$ \\
\hline 1. & Fabaceae & Prosopis africana & Iron tree/Kirya & $* *$ & $*$ \\
\hline 2. & Combretacea€ & Anogeissus leiocarpus & African birch/Marke & $* * *$ & $*$ \\
\hline 3. & Bombacacea & Ceiba pentandra & kapok tree/Rimin daji & $* * *$ & $*$ \\
\hline 4. & Balanitaceae & Balanites aegyptiaca & Desert date/Aduwa & $* * *$ & $*$ \\
\hline 5. & Rhamnaceae & Ziziphus spina-christi & Christi thorn/Kurna & $* * *$ & $*$ \\
\hline 6. & Fabaceae & Tamarindus indica & Tamarind/Tsamiya & $* * *$ & $*$ \\
\hline 7. & Meliceae & Khaya senegalensis & African mahogany/Madac & aci $* * *$ & $*$ \\
\hline 8. & Malvaceae & Sterculia setigera & Gum tree/kukkuki & $* * *$ & $*$ \\
\hline 9. & Malvaceae & Adansonia digitata & Baobab tree/kuka & $* * *$ & $*$ \\
\hline 10. & Fabaceae & Parkia biglobosa & Locus bean/Dorowa & $* * *$ & $*$ \\
\hline 11. & Sapotaceae & Vitellaria paradoxa & Shea butter/Kadanya & $* * *$ & $* *$ \\
\hline 12. & Verbenaceae & Vitex doniana & Black plum/Dinya & $* * *$ & $* *$ \\
\hline 13. & Fabaceae & Acacia sieberiana & Paperback thorn/Fararkaya & $*$ & $*$ \\
\hline 14. & Moraceae & Ficus sycomorus & Sycamore fig/Baure & $*$ & $*$ \\
\hline \multicolumn{6}{|c|}{ B-Shrub species } \\
\hline 1. & Annonaceae & Annona senegalensis & custard apple/Gwandan daji & $* *$ & $* *$ \\
\hline 2. & Balanitaceae & Balanites aegyptiaca & Desert date/Aduwa & $* * *$ & $*$ \\
\hline 3. $\mathrm{F}$ & Fabaceae & Deterium microcarpum & Tallow tree/Taura & $* * *$ & $*$ \\
\hline 4. $\mathrm{F}$ & Rhamnaceae & Ziziphus mauritiania & Jujube/Magarya & $* * *$ & $* *$ \\
\hline 5. $\mathrm{F}$ & Fabaceae & Piliostigma reticulatum & Camel's foot/Kargo & $* *$ & $*$ \\
\hline
\end{tabular}


6. Combretaceae Guinera senegalensi

7. Fabaceae Acacia sieberiana

8. Moringaceae Moringa oleifera

9. Rhamnaceae Ziziphus spina-christi

10. Meliaceae Azadirachta indica

11. Fabaceae Acacia ataxacantha

\section{C- Herbaceous plants}

1. Malvaceae Waltheria indica

2. Malvaceae Hibicus asper

3. Ascepiadaceae Leptadenia hasta

4. Pedaliceae Ceratotheca sasamoides false sesame/Karkashin daji

5. Malvaceae Urena lobota

6. Euphorbiaceae Croton lobatus
Egyptian mimosa/Sabara

Paperback thorn/Farar kaya *

Drum stick/Zogalle

Christi's thorn/Kurna

Neem/Dogon yaro

Flame thorn/Sarkakiya
$* * \quad *$

$*$

$* * * \quad *$

** $\quad *$

$* * * \quad *$

*

Sleepy morning/ Hankufa $\quad * * * \quad * *$

Frog roselle/Yakuwar kwad $\quad * * \quad * *$

Akamongot/yadiya $*$ * *

$* * * \quad * *$

$* * \quad *$

$* * \quad *$

$*=$ occasionally visited $; *=$ frequently visited $; * *=$ more frequently visited.

Table.2 Tree species Density and utilization by bees in the study Area (District I Mayo-Belwa)

\begin{tabular}{llll}
\hline S/N & Species & Means Density $($ Per/hectare $)$ & Utilization
\end{tabular}

1. Vitellaria paradoxum

$4.000^{\mathrm{a}}$

UT

2. Vitex doniana

$3.222^{\mathrm{b}}$

UT

3. Anogeissus leocarpus

$3.000^{\circ}$

UT

4. Ceiba pentandra

$3.000^{\circ}$

UT

5. Tamarindus indica

$3.000^{\circ}$

UT

6. Khaya senegalensis

$3.000^{\circ}$

UT

7. Parkia biglobosa

$2.800^{b}$

UT

8. Prosopis africana

$2.250^{\circ}$

UT

9. Sterculia setigera

2.200

UT

10. Ziziphus spina-christi

$2.200^{\circ}$

UT

1I. Balanites aegyptiaca

$1.700^{\circ}$

UT

12. Adansonia digitata

$1.500^{\circ}$

UT

13. Acacia sieberiana

$1.000^{\mathrm{d}}$

NUT

14. Ficus sycomorus

$1.000^{\mathrm{d}}$

NUT

Means values with the same superscripts are not significantly different at $(\mathrm{P}<0.05)$; UT $=$ Utilized; NUT= Not utilized 
Table.3 Tree species Density and utilization by honeybees in the study area (District 2 Binyeri)

\begin{tabular}{|c|c|c|c|}
\hline $\mathbf{S} / \mathbf{N}$ & Species & Mean Density (Per/ hectare) & Utilization \\
\hline 1. & Vitex doniana & $4.500^{a}$ & UT \\
\hline 2. & Vitellaria paradoxum & $3.500^{b}$ & UT \\
\hline 3. & Khaya senegalensis & $3.400^{c}$ & UT \\
\hline 4. & Tamarindus indica & $3.400^{c}$ & UT \\
\hline 5. & Anogeissus leocarpus & $3.000^{c}$ & UT \\
\hline 6. & Ceiba pentandra & $3.000^{c}$ & UT \\
\hline 7. & Parkia biglobosa & $2.800^{\circ}$ & UT \\
\hline 8. & Prosopis africana & $2.500^{c}$ & UT \\
\hline 9. & Balanites aegyptiaca & $2.000^{\mathrm{d}}$ & UT \\
\hline 10. & Ziziphus spina-christi & $2.000^{\mathrm{d}}$ & UT \\
\hline 11. & Ficus sycomorus & $1.700^{\mathrm{d}}$ & UT \\
\hline 12. & Sterculia setigera & $1.600^{\mathrm{d}}$ & UT \\
\hline 13. & Adansonia digitata & $1.600^{\mathrm{d}}$ & UT \\
\hline 14. & Acacia sieberiana & $1.500^{\mathrm{d}}$ & NUT \\
\hline
\end{tabular}

Mean values with the same superscripts are not significantly different at $(\mathrm{P}<0.05)$.

UT= Utilized; NUT= Not utilized

Table.4 Comparison of tree species density of the two districts in the study area (means values)

\begin{tabular}{cl}
\hline Mean values/ hectare & Districts \\
\hline $36.500^{\mathrm{a}}$ & 2 (Binyeri) \\
$33.872^{\mathrm{b}}$ & (Mayo-belwa) \\
\hline
\end{tabular}

There is significant different at $(\mathrm{P}<0.05)$.

Table.5 Shrub species Density and utilization by bees in the study Area (District 1 Mayo-Belwa)

S/N Species $\quad$ Means Density (Per/hectare) $\quad$ Utilization

\begin{tabular}{lcc}
\hline 1. Annona senegalensis & $5.500^{\circ}$ & UT \\
2. Guinera senegalensis & $5.400^{\circ}$ & UT \\
3. Detarium microcarpum & $4.200^{\circ}$ & UT \\
4. Balanites aegyptiaca & $4.000^{\circ}$ & UT \\
5. Ziziphus mauritiana & $4.000^{\circ}$ & UT \\
6. Piliostigma reticulatum & $2.400^{d}$ & UT \\
7. Azadirachta indica & $2.000^{\star}$ & UT \\
8. Acacia sieberiana & $1.800^{\star}$ & UT \\
9. Acacia ataxacantha & $1.600^{\star}$ & NUT \\
10. Ziziphus spina-christi & $1.000^{\circ}$ & UT \\
11. Moringa oliefera & $1.000^{\circ}$ & UT \\
\hline Means values with the same superscripts are not significantly different at $(\mathrm{P}<0.05)$.
\end{tabular}


Table.6 Shrubs Species Density and Utilization by bees in the study area (District 2 Binyeri)

\section{S/N Species $\quad$ Means Density (Per/hectare) $\quad$ Utilization}

\begin{tabular}{lll}
\hline 1. Annona senegalensis & $4.800^{\circ}$ & UT \\
2. Guinera senegalensis & $4.600^{\circ}$ & UT \\
3. Ziziphus mauritiana & $4.000^{\circ}$ & UT \\
4. Detarium microcarpum & $3.400^{\circ}$ & UT \\
5. Balanites aegyptiaca & $3.200^{\circ}$ & UT \\
6. Azadirachta indica & $2.000^{\circ}$ & UT \\
7. Piliostigma reticulatum & $1.800^{\text {a }}$ & UT \\
8. Ziziphus spina-christi & $1.700^{\text {a }}$ & UT \\
9. Moringa oliefera & $1.000^{\circ}$ & UT \\
10. Acacia sieberiana & $1.000^{\circ}$ & NUT \\
11. Acacia ataxacantha & $1.000^{\circ}$ & NUT
\end{tabular}

Means values with the same superscripts are not significantly different at $(\mathrm{P}<0.05)$

UT= Utilized; NUT= Not utilized

Table.7 Comparison of shrub Species density of the two districts in the study area (mean values)

\begin{tabular}{cl}
\hline Means values/hectare & Districts \\
\hline $32.900^{\mathrm{a}}$ & 1(Mayo-Belwa) \\
$28.500^{\mathrm{b}}$ & 2(Binyeri) \\
\hline
\end{tabular}

There is significant different at $(\mathrm{P}<0.05)$

Table.8 Percentage cover of herbaceous plant utilized by honeybees in the study area

\section{Means values/hectare Districts}

$\begin{array}{ll}70.400^{\mathrm{a}} & 1(\text { Mayo-Belwa) } \\ 58.800^{\mathrm{b}} & \text { 2(Binyeri) }\end{array}$

There is significant different at $(\mathrm{P}<0.05)$

Table.9 Effects of ecological factors on the yield of honey in the study area

\begin{tabular}{lcc}
\hline Variables & $\begin{array}{c}\text { Parameter Estimate } \\
\text { (Coefficients) }\end{array}$ & Standard Error \\
\hline Intercepts & $20.989^{\mathrm{ns}}$ & \pm 31.529 \\
Rainfall & $-0.207^{\mathrm{ns}}$ & \pm 0.166 \\
Relative humidity & $1.492^{* *}$ & \pm 1.614 \\
Temperature & $-3.476^{\mathrm{ns}}$ & \pm 3.837 \\
Tree density & $0.524^{*}$ & \pm 6.514 \\
\hline$* *=$ Highly significant at $(\mathrm{P}<0.05) ;^{*}=$ significant at $(\mathrm{P}<0.05) ; n s=$ not significant at $(\mathrm{P}<0.05)$ \\
$\mathrm{CV}=9.209 \mathrm{R}^{2}=0.176 ;$ Values are corresponding with standard error.
\end{tabular}


The results of tree species density in MayoBelwa and Binyeri districts utilized by honeybees in the study area are $85.7 \%$ and $92.9 \%$ respectively of the identified species while the results of shrubs species density in Mayo-Belwa and Binyeri districts utilized by honeybees in the study area are $90.9 \%$ and $81.8 \%$ respectively of the identified species. Therefore the results are sufficiently indicative of high ecological potentials for beekeeping in the study area and this finding is in consonance with that of (Equar et al., 2016) who recorded high potential diversity of honeybee plant resources mostly in closed forest site. Also the results are in agreement with the findings of (Kifle et al., 2014) who confirmed that visiting and utilization of plant species intensity and time by honeybees were significantly different. Therefore, apart from the low status of herbaceous layer in district 2 , the result of the herbaceous cover and utilization are sufficiently indicative of high ecological potentials of the two districts for beekeeping as confirmed by (Shailaja et al., 2016) who revealed that honeybees plants are crucial for the establishment of beekeeping industry.

The results of the effects of climatic factors and plants density on the yield of honey in the study area agreed with the findings of Mutsaers (1992) who observed that too low $\left(8^{\circ} \mathrm{C}\right)$ and too high (above $\left.50^{\circ} \mathrm{C}\right)$ temperatures as well as relative humidity below $50 \%$ can affect lying of eggs, destruction of the larvae and activeness of the honeybees. However, the ambient temperature in the study area range from $25^{\circ} \mathrm{C}$ to $33^{\circ} \mathrm{C}$ throughout the year, and the relative humidity rarely falls below $50 \%$. This perhaps explains why relative humidity and plant factors are the major determinants of the yield of honey in the study area. The plants do not only provide food for the honeybees, they also provide shelter or homes for the honeybees. Most colonies of honeybees build their hives in or on trees trunks; hence availability and presence of honeybee's plant resources are very essential for the yield of honey reported by (Bareke et al., 2017).

From the results obtained it can be concluded that the study area (Mayo-Belwa local Government area of Adamawa state, Nigeria) contains abundant plant resources required by honeybees for both food and cover. Relative humidity and plant species density which are the key factors in determining the honeybee's population and yield of honey are adequate in the study area. It is therefore, not out of place to conclude from this finding that the ecological potentials of beekeeping in the study area are reasonable high, which calls for beekeeping industry in the area.

\section{References}

Adebayo, A.A and Tukur, A.L. (1999). Adamawa State in Maps, paraclete Publishers, Yola, Nigeria. Pp. 3-4.

Akobundu, I.O. and Agyakwa, C.W. (1998).A hand book of West African weeds. International Institute of Tropical Agriculture Ibadan, Nigeria Pp.1-564.

Akosim, C., Kwaga, B.T., Amadi, D.C.A., Inah, E.I. (2007). Ecological potentials of Beekeeping in Adamawa State. In: $A n$ International Journal of Agricultural Sciences, Science Environment and Technology (ASSET) University of Agriculture, Abeokuta, Nigeria, 6(1): 67-76.

Akosim, C., Tella, I.O. and Jatau, D.F. (1999). Vegetation and forest resources. In: Adamawa state in maps. Edited by Adebayo, A.A. and Tukur, A.L. paraclete-publishers, Yola- Nigeria, Pp. 32-35.

Bareke, T., Admasu, A. and Kibebew, W. (2017). Screening of potential shrubs for bee foraged development. Journal of Plant Sciences, 5(5): 160-164.

Beetsma, J., Kaal, T., Mulder, V. and Sommeijer, R. (1997). Beekeeping in the tropics, $3^{\text {rd }}$ edition. C.T.A., Wageinager, the Netherlands.

Brian, M.V. (1983). Ecology and Behavioural Biology of social insects. Chapman and Hall, 
New York, Pp. 24-385.

Campbell, M.V. and Lesley. (1985). Honey production and bee wax, the African perspective.

Carol, K.M. (2003). Annual Workshop for Beginner in Beekeeping, spring sting bee flying, Texas - U.S.A Pp. 1-4.

Curtis, G. and Stacey, L. (1982). Small Scale beekeeping: Information Collection and Exchange Manual, Peace Corps, Washington DC Pp. 23-73.

Equar, G., Abraha, B., Lemna, H., Amare, S. and Asmelash, T. (2016). Honeybee flora diversity and their impact on honey production in Tigray region of Ethiopia. Livestock Research for Development, 28(7): Article no. 122.

Gomez, K.A. and Gomez, A.A. (1984). Statistical procedures for Agricultural research, $2^{\text {nd }}$ edition John Willey and Son Limited. Pp. 2029.

Ijomah, J.U. and Akosim, C. (2000). Element of biological conservation ( $1^{\text {st }}$ Edition). Trinity Graphics System Ltd. Jos, Nigeria. Pp. 1-30.

Ikediobi, C.O. and Obi, V.C. (1985). Beekeeping and honey production in Nigeria. The Nigerian field No. 50 part 3 and 4; 59-70.

Kifle, T.B., Kibebew, W.H. and Admasu, A.M. (2014). Screening of Potential herbaceous plants for beekeeping development. Agriculture, Forestry and Fisheries, 3(5): 386-391.

Marieke, M. (1991). Bee in their Natural Environment in South Western Nigeria. The Nigerian Field No. 58, Pp. 2-8. http://www.maplandia.com/Nigeria/ adamawa/mayo-belwa, Google map, retrieved on 12 April, 2019.
Mutsaers, M. (1992). The development of seasonal beekeeping method in southwestern Nigeria. Paper presented at $5^{\text {th }}$ international conferences on Beekeeping in Tropical climate; IBRA, Trinidad and Tobago Pp7-12.

Onyekuru, J.E. (1985). Challenges of Wildlife Conservation in Tropical Africa. Seminar Paper Presented at the University of Ibadan. Pp. 1-16.

Reda, G.K., Shishay, G. and Belets, G. (2018). Beekeeping practice and honey production potential in Afar regional state, Ethiopia. Journal of Agriculture and Environmental, 10: 66-82.

Reinhard, F. (1997). Trees Bee use. The journal for sustainable beekeeping. Troy Monmouth, U.K, No 44 p5.

Reinhard, F. (1995a). Trees Bee use. The Journal for Sustainable Beekeeping. Troy Monmouth, U.K, No 36 P.10 (1995b) - No 41 P 11.

Shailaja, H., A.B. Gawate and Bharat, S. (2016). Bee floral diversity of medicinal plants in Vidya Pratishthan campus, Baramti, Pune district (M.S.), India. Int. J. Curr. Microbiol. App. Sci. 5(11): 425-431.

Sutherland, W. J. (1999). Ecological census techniques $1^{\text {st }}$ Edition: A Handbook. Cambridge University press U.K Pp. 73-81, 11-123.

Swamy, R. R. (2002). Agricultural Statistics. $2^{\text {nd }}$ Edition. New Age international, New Dell Pp. 1-497.

Wahua, T. A. T. (1999). Applied statistics for scientific studies. Africa link books, Ibadan, Nigeria. Pp. 1-356.

Wanda, E. (2003). Great Good desert (HoneyFree save the bees) Baklava. The Book Publishing Company, Texas U.S.A. Pp. 1-4.

\section{How to cite this article:}

Mohammed Abdullahi, Amit Larkin, Hemant Kumar and Kwaga, B.T. 2019. Ecological Potentials of Beekeeping in Mayo-Belwa Local Government Area of Adamawa State, Nigeria. Int.J.Curr.Microbiol.App.Sci. 8(05): 1264-1273. doi: https://doi.org/10.20546/ijcmas.2019.805.144 